\title{
Characteristics of the surface rupture associated with the 2004 Mid Niigata Prefecture earthquake, central Japan and their seismotectonic implications
}

\author{
Tadashi Maruyama, Yuichiro Fusejima, Toshikazu Yoshioka, Yasuo Awata, and Tabito Matsu’ura \\ Active Fault Research Center, Geological Survey of Japan, National Institute of Advanced Industrial Science and Technology, \\ Tsukuba 305-8567, Japan
}

(Received February 10, 2005; Revised May 25, 2005; Accepted May 25, 2005)

\begin{abstract}
The 2004 Mid Niigata Prefecture earthquake sequence produced a nearly 1-km-long, N-S to NNW-SSEstriking, west-side-up surface rupture along a previously unmapped fault at Obiro, Uonuma City, eastern margin of the epicentral region. The maximum vertical displacement is $20 \mathrm{~cm}$. The topographic and geometric features of the surface rupture are indicative of reverse faulting with dip to the west, which is consistent with focal mechanism solutions and aftershock distribution. Along the major active faults and folds that form the framework of landforms in the epicentral region, systematic surface ruptures were not found. Exceptionally small rupture dimension and offset amount of the surface rupture compared with those of the modeled fault suggest that the fault slip appears to have been accommodated by both internal deformation in thick Neogene-Quaternary deposits and growth of the folds and blind thrusts around the epicentral region.
\end{abstract}

Key words: Surface rupture, reverse fault, 2004 Mid Niigata Prefecture earthquake, tectonics.

\section{Introduction}

On October 23, 2004, a shallow earthquake sequence with maximum magnitude of $\mathrm{M}_{\mathrm{JMA}} 6.8\left(\mathrm{M}_{\mathrm{W}} 6.6\right)$ struck the mid-Niigata region, northern central Japan (Fig. 1). The mainshock and major aftershocks have thrust-type focal mechanisms with WNW-ESE-trending principal axis of horizontal compression (National Research Institute for Earth Science and Disaster Prevention, 2004). The recent crustal deformation of the epicentral region is characterized by active thrust faulting and folding, thus this earthquake sequence may provide insight into understanding of relationship between the earthquake faulting and growing process of geologic structures.

Immediately after the earthquake, an urgent field investigation team was organized in Active Fault Research Center, GSJ/AIST, for the purpose of checking whether or not the surface ruptures associated with the earthquake were appeared and understanding the deformational mechanisms in active fold-and-thrust zones. As a result of one-month-long fieldwork, ca. 1-km-long well-defined surface rupture was found at the Obiro area, Uonuma City, eastern part of the epicentral region (Maruyama et al., 2004, 2005).

In this paper, we present morphological characteristics of the surface rupture and discuss their seismotectonic implications around the epicentral region.

Copy right(c) The Society of Geomagnetism and Earth, Planetary and Space Sciences (SGEPSS); The Seismological Society of Japan; The Volcanological Society of Japan; The Geodetic Society of Japan; The Japanese Society for Planetary Sciences; TERRAPUB.

\section{Tectonic Setting}

The NNE-SSW to NE-SW-striking folds and thrust faults widely develop in Neogene-Quaternary sequences of the northern part of central Japan (Fig. 1). The Neogene sequences were deposited in rifts, which formed in the early Miocene period, concurrently with the opening of the Japan Sea, and subsequently they have been folded and faulted under E-W to WNW-ESE compressional stress field since Pliocene time (e.g., Okamura, 2003). This compression continued during the Quaternary period and is expressed as deformed Quaternary strata, tectonic landforms, and contemporary earthquake activity.

Based on the late Quaternary geologic and geomorphic features, several NNE-SSW to NE-SW-striking active reverse faults, flexures, and folds have been reported in and around the epicentral region (e.g., Yanagisawa et al., 1986; Research Group for Active Faults of Japan, 1991; Watanabe et al., 2001, Figs. 1 and 2(a)). Paleoseismic activities of these active structures are, however, poorly known. Several historical moderate earthquakes are recorded around the epicentral region (e.g., Usami, 2003), but surface ruptures associated with these events were not documented.

\section{Characteristics of the Surface Rupture}

The field investigations revealed that a nearly $1-\mathrm{km}$-long surface rupture occurred along a previously unmapped fault at Obiro, eastern part of the epicentral region. The surface rupture, trending $\mathrm{N}-\mathrm{S}$ to $\mathrm{NNW}-\mathrm{SSE}$, truncates obliquely a few levels of fluvial terraces (Figs. 2 and 3(a)). The surface rupture has the following characteristics; (1) the rupture generally forms a narrow deformation zone of 5-50 $m$ wide; (2) the deformation zone is mainly composed of contractional features such as thrust faulting and flexuring 


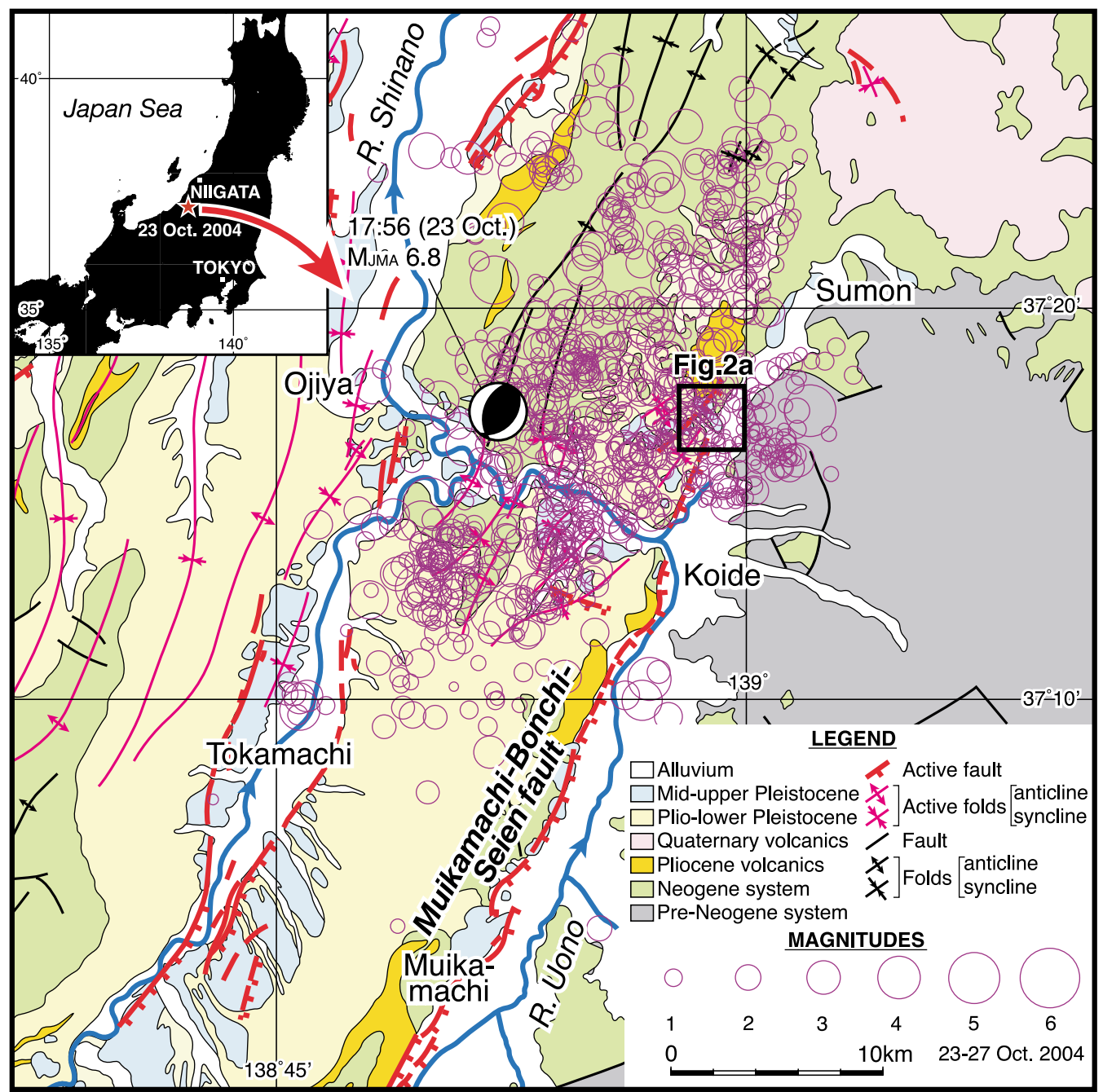

Fig. 1. Neotectonic map around the epicentral region of the 2004 Mid Niigata Prefecture earthquake, showing major active tectonic features and earthquakes recorded from 23 to 27 October 2004 (base map is simplified from Kato and Yamazaki, 1979; Watanabe et al., 2001; Nakata and Imaizumi, 2002). The mainshock and major aftershocks have thrust-type focal mechanisms with WNW-ESE-trending principal axis of horizontal compression (National Research Institute for Earth Science and Disaster Prevention, 2004), which is consistent with Quaternary stress field as inferred from deformations of Quaternary strata and geomorphic surfaces. Lower hemisphere CMT focal mechanism of the main shock is from Japan Meteorological Agency (2004)

in the rice and vegetation fields, and bending and buckling deformations on concrete and asphalt structures; (3) the surface rupture has a west-side-up vertical component; (4) both the vertical and shortening amounts as estimated using man-made piercing points are smaller than $20 \mathrm{~cm}$. Here, we describe the surface rupture in detail from north to south.

Within the cultivated area, man-made structures such as asphalt roads, concrete pipes built in the roads, and concrete irrigation ditches were offset and shortened in a N-Strending narrow zone (Locs. 1 and 3, Figs. 2 and 3(b)). On these locations, the compressional direction is inferred to be $\mathrm{E}-\mathrm{W}$ to WNW-ESE by restoring the deformed structures to their original forms. Between Loc. 1 and Loc. 3, the clear surface rupture was developed to form distinct fault scarp across vegetation field (Loc. 2, Figs. 2(b) and 3(c)).

From cultivated area of Obiro southward to the eastern bank of the Wada River, an unambiguous surface rupture, extending for $350 \mathrm{~m}$ in general strike of NNW-SSE, cuts across rice fields and intervening footpaths, road and embankment (Locs. 4-6, Figs. 2(b), 3(a), (d) and (e)). Detailed mapping demonstrates, however, that the surface rupture is highly sinuous ranging from NNW-SSE to NE-SW as shown in Fig. 2(b). The NNW-SSE-striking section shows an apparent sinistral offset whereas NE-SW-striking one has an apparent dextral offset although both have west-side-up vertical component. These geometrical features indicate that the surface rupture was formed due to E-W to WNWESE-trending compression, which is concordant with that inferred from restoration of the deformed man-made structures to the north.

To the south from the eastern bank of the Wada River, no measurable surface ruptures were developed although small compressional deformations in man-made structures were sporadically observed (Fig. 2(a)).

In order to understand deformational nature of the surface rupture, we conducted the topographic profiling using a total station. The displacements were measured along the rupture by means of offsets of originally flat and linear features such as rice fields and intervening footpaths and roads across the surface rupture. The displacements 


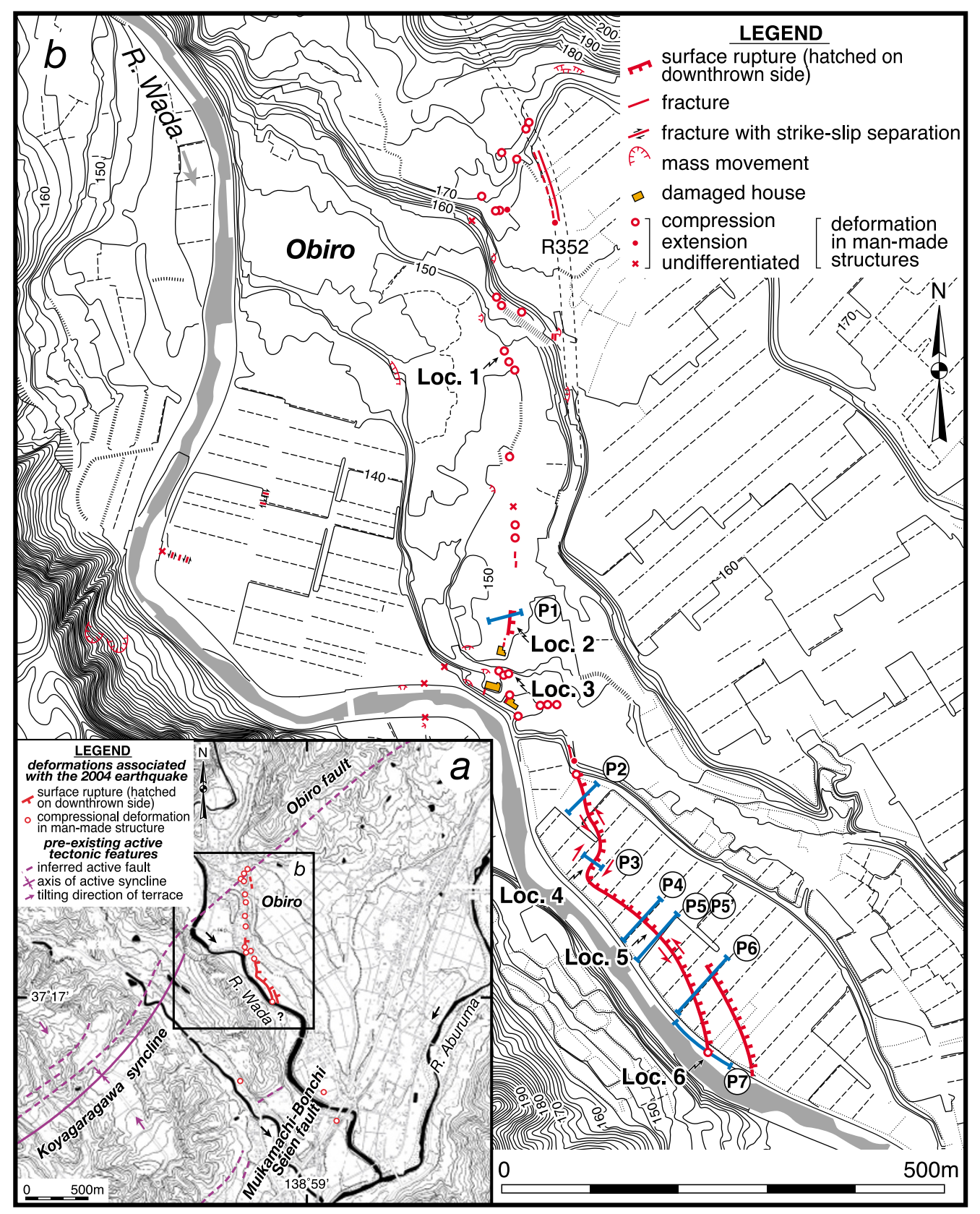

Fig. 2. (a) Distribution of surficial deformation around Obiro, Uonuma City. Note that the surficial deformations are distributed in nearly N-S-trending narrow zone along which the topographic contrast between hilly land to the west and fluvial lowland to the east is developed. Pre-existing active tectonics features are from Yanagisawa et al. (1986) and Watanabe et al. (2001). (b) Map showing detailed distribution of the surface rupture at Obiro. Locations of topographic profiling using a total station are also shown. Background topographic contour map is redrawn from 1/2,500 map (contour interval: $2 \mathrm{~m}$ ) published by former Hirokami Village, Niigata Prefecture.

were measured at eight sections. As shown in Fig. 4, originally flat vegetation and rice fields and intervening footpaths are deformed by $10-20 \mathrm{~cm}$ vertically with west-sideupthrown. The topographic profiling also provides information on morphological characteristics of the surface rupture. The surface rupture is characterized by flexure, pressure ridge, and back-tilting (Fig. 4).

\section{Discussion and Conclusions}

We reported morphological characteristics of the surface rupture associated with the Mid Niigata Prefecture earthquake. The nearly 1-km-long surface rupture has general strike of N-S to NNW-SSE and west-side-up vertical com- ponent. Geometrically, the surface rupture is characterized by sinuous trace (Figs. 2 and 3). Topographic profiles across the surface rupture display flexure, pressure ridge, and back-tilting on the upthrown side (Fig. 4). These morphological features of the surface rupture are indicative of west-dipping reverse faulting (e.g., Carver and McCalpin, 1996; Yeats et al., 1997), which is consistent with seismological observations such as focal mechanism solutions and spatial distribution of the main- and aftershocks (e.g., Japan Meteorological Agency, 2004; National Research Institute for Earth Science and Disaster Prevention, 2004; Hirata et al., 2005, Fig. 1). We, therefore, infer that the surface rupture is related to the seismogenic fault slip. 

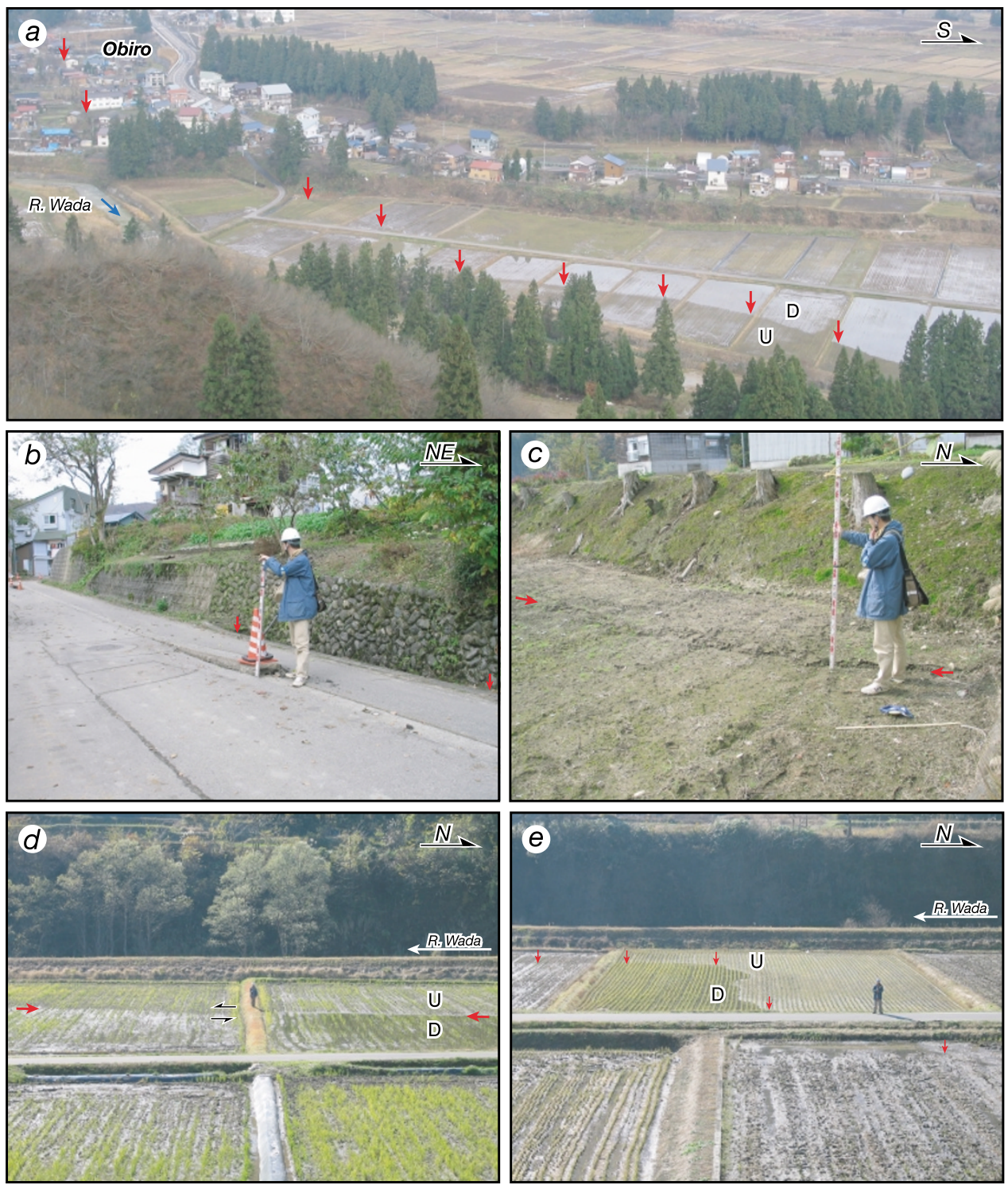

Fig. 3. Photos showing natures of the surface rupture at Obiro. (a) Perspective view of the surface rupture displacing the rice fields. Red arrows mark the rupture which is demonstrated clearly by difference in water level in the fields. The rupture occurred on a low relief ground surface, thus the tectonic features were clearly visible. $\mathrm{U}$ and $\mathrm{D}$ show upthrown and downthrown sides, respectively. (b) Push-up of the concrete pipe built in asphalt road due to WNW-ENE compression (Loc. 3). Concrete irrigation ditch is also deformed due to shortening (shown in red arrows). Shortening amount using tape is estimated to be $\sim 10 \mathrm{~cm}$. (c) Southwest-looking view of the surface rupture displacing vegetation field (Loc. 2). At this site, the rupture has N-S strike with west-side-up vertical component. Note that the surface rupture (shown in red arrows) occurs at the base of pre-existing east-facing scarp. (d) West-looking view of straight section of the surface rupture (Loc. 5). The rice fields and an intervening footpath are displaced vertically and sinistrally by $15 \pm 5 \mathrm{~cm}$ and $17 \pm 3 \mathrm{~cm}$, respectively. (e) Sinuous section of the rupture, viewed from east (Loc. 4). In this section, the segment of NNW-SSE strike has a sinistral offset of $18 \pm 3 \mathrm{~cm}$ whereas that of NE-SW strike has a dextral offset of $10 \pm 3 \mathrm{~cm}$. These show that the surface rupture was generated by WNW-ESE-trending compression, which is consistent with focal mechanisms of main- and major aftershocks.

The 2004 surface rupture occurred along which no active fault was mapped prior to the earthquake. Geomorphologically, the surface rupture appeared at the topographic boundary between hilly land to the west and lowland to the east (Figs. 2(a) and 3(a)). At Loc. 2 the surface rupture occurred at the base of 2-m-high pre-existing east-facing scarp on a fluvial terrace (Figs. 2(b), 3(c) and 4). These westside-up topographic features are concordant with that of the surface rupture. Thus, this N-S- to NNW-SSE-trending topographic contrast might have resulted from recurrent westside-up faulting during the Quaternary and the surface rupture appeared along the pre-existing active fault. In order to assess this speculation, further investigations including the detailed mapping of tectonic landforms, trenching, and seismic profiling across the surface rupture are required.

In and around the epicentral region, there are several major active reverse faults and folds including the Muikamachi-Bonchi-Seien fault (active fault in the western margin of the Muikamachi Basin) and the Obiro fault (e.g., Research Group for Active Faults of Japan, 1991; Watanabe et al., 2001, Figs. 1 and 2(a)). These structures accompany significant geomorphic expressions indicating recurrent surface faulting during the late Quaternary. Our detailed field investigations show that the systematic and distinct surface ruptures as observed at Obiro were not identified along these active structures although a large num- 

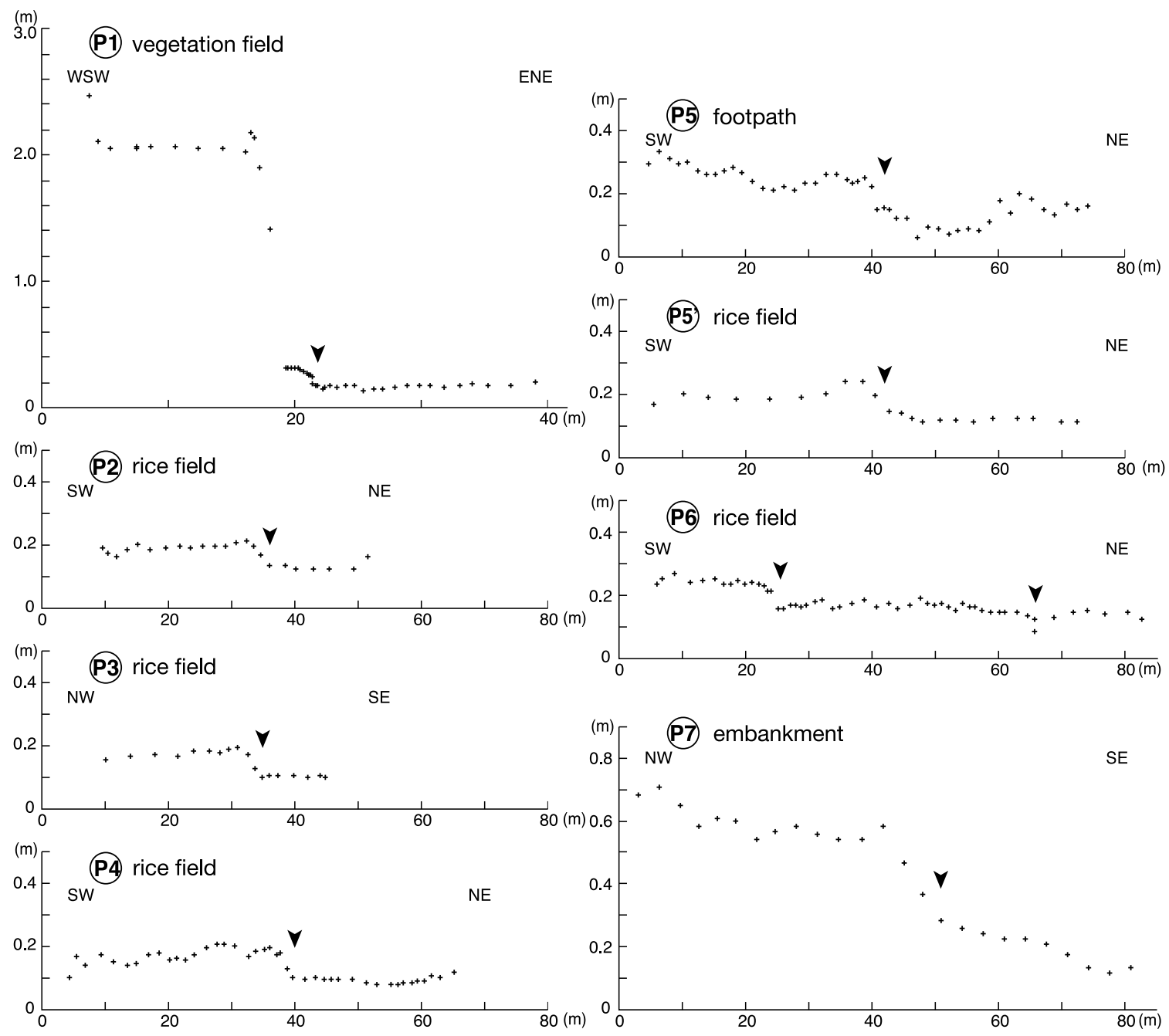

Fig. 4. Topographic profiles using a total station across the surface rupture at Obiro. For locations of the profiles see Fig. 2(b). Note that the vertical exaggeration for the profiles P2-P7 is $\times 50$ but that for the profile P1 is $\times 10$. Arrowheads mark the locations of the surface rupture. The west-side-up vertical offset along the rupture is measured to be $10-20 \mathrm{~cm}$. The surface rupture is characterized by flexure, bulge, and back-tilt on the vegetation and rice fields, which are general topographic features of reverse faulting. Note that the 2004 surface rupture occurred at the base of the pre-existing east-facing scarp at Loc. 2 (See Fig. 2(b)).

ber of landslides and fissures were developed. These preexisting active structures, therefore, should be considered prime candidates for generating future destructive earthquakes accompanying with surface ruptures.

Seismological studies indicated that the rupture initiated at a depth of ca. $13 \mathrm{~km}$ and extended along over $20-\mathrm{km}-$ long NNE-SSW-trending NW dipping reverse fault (e.g., Hirata et al., 2005; Honda et al., 2005, Fig. 1). Net slip at depth was estimated to be as much as $3.8 \mathrm{~m}$ based on waveform inversion of strong ground motion data (Honda et al., 2005). However, the rupture dimension and offset amount at the surface were considerably small as documented above (Figs. 2-4). In the epicentral region, many folds and thrusts affect the thick Neogene-Quaternary deposits (Yanagisawa et al., 1986, Fig. 1). Thus, the fault slip possibly has been taken up by both the internal deformations in thickly accumulated Neogene-Quaternary strata and the growth of the folds and blind thrusts around the epicentral region, which are hard to detect visibly.

Acknowledgments. The authors express their gratitude to $\mathrm{K}$.
Yoshida for locating the mainshock and aftershocks which are plotted in Fig. 1 and to K. Mizuno, R. Imura, T. Ishiyama, T. Komatsubara and $\mathrm{H}$. Kurosawa for field assistance. We also thank to Y. Sugiyama, T. Azuma, H. Horikawa, M. Saito and T. Matsuda for helpful discussions and K. Satake for revision of an early version of the manuscript. We are grateful to Prof. N. Hirata and an anonymous reviewer for their comments and suggestions that greatly improved this paper.

\section{References}

Carver, G. A. and J. P. McCalpin, Chapter 5 Paleoseismology of compressional tectonic environments, in Paleoseismology, edited by J. P. McCalpin, pp. 183-270, Academic Press, California, 1996.

Hirata, N., H. Sato, S. Sakai, A. Kato, and E. Kurashimo, Fault system of the 2004 Mid Niigata Prefecture Earthquake and its aftershocks, Landslides, 2, doi: 10.1007/s10346-005-0050-8, 2005.

Honda, R., S. Aoi, N. Morikawa, H. Sekiguchi, T. Kunugi, and H. Fujiwara, Ground motion and rupture process of the 2004 Mid Niigata Prefecture earthquake obtained from strong motion data of K-NET and KiK-net, Earth Planets Space, 57, this issue, 527-532, 2005.

Japan Meteorological Agency, CMT analysis with JMA broadband seismograph network, http://www.seisvol.kishou.go.jp/eq/mech/outer/cmt/ event/0410231756_.html, last accessed 28 Dec. 2004, 2004 (in Japanese).

Kato, H. and H. Yamazaki, Neotectonic map of Shin-etsu district in Japan, 
Tectonic map series 5, Geological Survey of Japan, 1979.

Maruyama, T., Y. Fusejima, T. Matsu'ura, Y. Awata, T. Yoshioka, K. Mizuno, R. Imura, T. Ishiyama, and T. Komatsubara, Urgent geological investigation on the surface rupture associated with the $2004 \mathrm{Mid} \mathrm{Ni-}$ igata Prefecture earthquake, Chishitsu News, 604, 1, 2004 (in Japanese).

Maruyama, T., Y. Fusejima, T. Yoshioka, and Y. Awata, Report on urgent geological investigation along the surface rupture associated with the 2004 Mid Niigata Prefecture earthquake, Seismol. Soc. Japan Newsletter, 16(5), 33-34, 2005 (in Japanese).

Nakata, T. and T. Imaizumi (eds.), Digital Active Fault Map of Japan, 60 pp. with 2 DVD-ROM, University of Tokyo Press, Tokyo, 2002 (in Japanese).

National Research Institute for Earth Science and Disaster Prevention, 2004 Mid Niigata Earthquake, http://www.hinet.bosai.go.jp/topics/ niigata041023/index_e.html, last accessed 28 Dec. 2004, 2004.

Okamura, Y., Fault-related folds and an imbricate thrust system on the northwestern margin of the northern Fossa Magna region, central Japan, The Island Arc, 12, 61-73, 2003.

Research Group for Active Faults of Japan, Active Faults in Japan: Sheet
Maps and Inventories (Revised edition), 437 pp., University of Tokyo Press, Tokyo, 1991 (in Japanese with English summary).

Usami, T., Materials for Comprehensive List of Destructive Earthquakes in Japan, [416]-2001 (Latest Edition), 605 pp., University of Tokyo Press, Tokyo, 2003 (in Japanese).

Watanabe, M., H. Tsutsumi, Y. Suzuki, H.-Y. Kim, and N. Sato, 1:25,000 Active Fault Map in Urban Area, Ojiya, D.1-No. 388, Geographical Survey Institute, 2001.

Yanagisawa, Y., I. Kobayashi, K. Takeuchi, M. Tateishi, K. Chihara, and H. Kato, Geology of the Ojiya district, With Geological Sheet Map at 1:50,000, Geological Survey of Japan, 177 pp, 1986 (in Japanese with English abstract 6 p).

Yeats, R. S., K. Sieh, and C. R. Allen, The Geology of Earthquakes, Oxford University Press, New York, 568 pp., 1997.

T. Maruyama (e-mail: tadashi-maruyama@aist.go.jp), Y. Fusejima, T. Yoshioka, Y. Awata, and T. Matsu'ura 